\title{
Root pruning reduces root competition and increases crop growth in a living mulch cropping system
}

\author{
Birgitta Båth $^{1}$, Hanne L. Kristensen ${ }^{2}$ and Kristian Thorup-Kristensen ${ }^{3}$ \\ ${ }^{1}$ SLU, Department of Crop Production Ecology, Box 7043, SE-750 07 Uppsala, Sweden \\ ${ }^{2}$ University of Aarhus, Department of Horticulture, DK-5792 Aarslev, Denmark \\ Contact: Birgitta Båth; E-mail:birgitta.bath@vpe.slu.se, Phone: +46 18672310
}

\begin{abstract}
Living mulch systems may decrease pest attacks. However, the below-ground competition from the living mulch may decrease the growth of the cash crop. Here growth of white cabbage in living mulch systems and in pure stands was compared. Root pruning of the living mulch increased the above-ground biomass of white cabbage, with two prunings giving higher cabbage yields than one. Below-ground growth and competition were examined by measuring root distribution in minirhizotrons and uptake of ${ }^{15} \mathrm{~N}$ placed at different soil depths. These studies showed that the ability of mulch species to compete for resources at depth was restricted by pruning.

KEYWORDS:living mulch, $\mathrm{N}$ competition, root distribution, root pruning, white cabbage
\end{abstract}

\section{INTRODUCTION}

One method to overcome pest attacks is intercropping. However, in intercropping systems with only one cash crop competition between the cash crop and the intercrop (the living mulch) often reduces the yield of the cash crop. Especially in intercropping systems used to prevent early pest attacks this constitute a problem as the living mulch must already be in full growth at the time of establishment of the cash crop which gives the living mulch a competitive advantage. The aboveground competition can be reduced by cutting the living mulch when the risk of pest attacks has declined. Below-ground competition may, however, be more important for the growth of the cash crop, especially during initial growth stages. The aim of this project was to investigate (i) the influence of root pruning of living mulches on aboveground biomass of white cabbage and the effect of number of prunings, (ii) root distribution and (iii) nitrogen $(\mathrm{N})$ uptake. The growth of white cabbage in pure stands was compared with that of the same cultivar grown in cropping systems with living mulch with or without root pruning of the living mulches.

\section{METHODS}

Two field experiments (I and II) were carried out at the Aarslev Research Centre in Denmark. Birdsfoot trefoil and salad burnet were used as living mulches in both experiments while red clover and winter rye were used only in exp. I. The broad seeded living mulches were, after emergence, row-rotovated to leave approximately $0.2 \mathrm{~m}$ wide rows of living mulch alternating with approx. $0.5 \mathrm{~m}$ stripes of bare soil, into which the cabbage was planted. The root pruning of the living mulches was carried out using a machine with overlapping blades cutting along both sides and below each strip of the living mulch crop at a depth of approx. $0.2 \mathrm{~m}$. The living mulches were root pruned twice in exp I and, once or twice in exp II. Minirhizotrons installed at an angle of $30^{\circ}$ from the vertical and reaching approx. $2.42 \mathrm{~m}$ depth were used to monitor root distribution. Root growth was observed with a minivideo camera using grids painted along the upper surface of the minirhizotrons. Uptake of $\mathrm{N}$ was measured by deep point ${ }^{15} \mathrm{~N}$ placement. The ${ }^{15} \mathrm{~N}$ was injected at depth $(0.15,0.90$ or $1.80 \mathrm{~m})$ through tubes situated mid-way between the white cabbage and living mulch rows. 


\section{RESULTS AND DISCUSSION}

The pruning of roots increased the aboveground biomass of white cabbage (Figure 1). In experiment II cabbage biomass was higher with two root prunings compared with one and there was no difference in aboveground biomass of white cabbage between intercropping with two prunings and the pure stand.
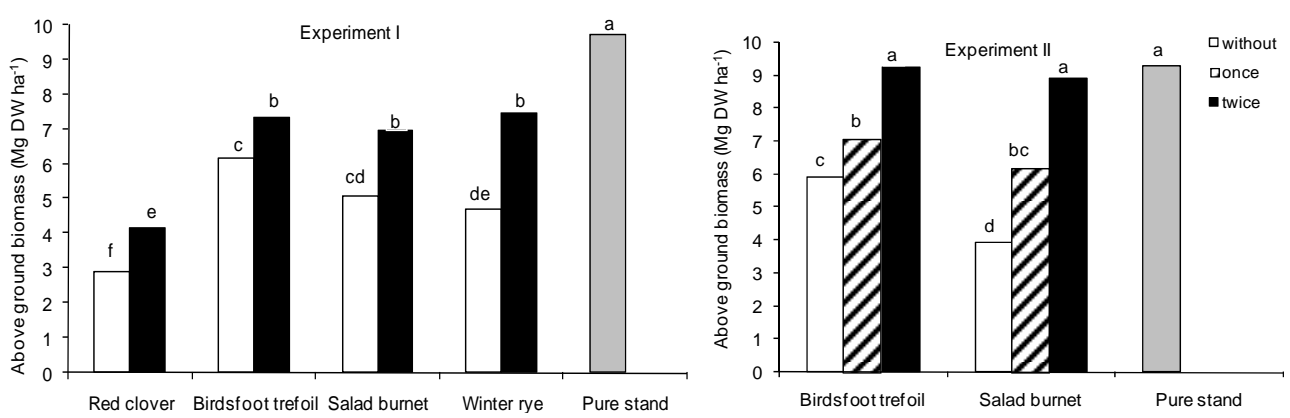

Figure 1. Aboveground biomass of white cabbage grown with and without a living mulch. Different letters indicate significant differences between bars $(\mathrm{p} \leq 0.05)$.

The results showed a decrease of ${ }^{15} \mathrm{~N}$ uptake at depth for the root pruned living mulches and a corresponding increase in white cabbage (Figure 2). Without root pruning, the living mulch strongly reduced the ability of white cabbage roots to grow deeply, whereas with root pruning the distribution of white cabbage roots was comparable to that of white cabbage growing in pure stand. The living mulch still had a significant competitive ability for ${ }^{15} \mathrm{~N}$ uptake from $0.15 \mathrm{~m}$ depth, which indicated that the reduced uptake from the deeper soil layers was not just an effect of overall weakened growth of the living mulch.



Figure 2. Percentage of supplied ${ }^{15} \mathrm{~N}$ that was taken up from $0.15,0.9$ and $1.8 \mathrm{~m}$ soil depth. Different letters indicate significant differences between bars $(p \leq 0.05)$.

In spite of the great effect of root pruning on white cabbage aboveground biomass, the effects on root distribution were few and inconsistent. With the minirhizotron method only overall effects on the combined root systems of the white cabbage and living mulch could be studied due to the inability of the method to distinguish between roots of different species. Consequently, the ${ }^{15} \mathrm{~N}$ and minirhizotron studies did not support each other.

Reference: Båth, B., Kristensen, H.L. \& Thorup-Kristensen, K. 2008. Root pruning reduces competition and increases crop growth in a living mulch cropping system. Journal of Plant Interactions 3, 211-221.

The project was financed by Formas, the Swedish Research Council for Environment, Agricultural Sciences and Spatial Planning. 